\title{
Association of coronary artery disease with toll-like receptor 4 genetic variants: A meta-analysis
}

\author{
Jianlong Sheng ${ }^{1,2, A-D, F}, \operatorname{Jian} X u^{1, A-F}$ \\ ${ }^{1}$ Department of Cardiology, Anhui Provincial Hospital of Anhui Medical University, Hefei, China \\ ${ }^{2}$ Department of Cardiology, The Second Affiliated Hospital of Anhui Medical University, Hefei, China \\ A - research concept and design; $B$ - collection and/or assembly of data; $C$ - data analysis and interpretation; \\ $D$ - writing the article; $E$ - critical revision of the article; $F$ - final approval of the article
}

\section{Address for correspondence \\ Jian Xu}

E-mail:xu_jian_AMU@protonmail.com

Funding sources

None declared

Conflict of interest

None declared

Received on 0ctober 14, 2017

Reviewed on December 18, 2017

Accepted on May 29, 2018

Published online on February 18, 2019

\begin{abstract}
Background. Toll-like receptor 4 (TLR4) plays an important role in the formation of coronary atherosclerotic plaque and the pathogenesis of coronary artery disease (CAD).

Objectives. The aim of the study was to conduct a meta-analysis assessing the relationship between 2 common genetic variants in the TLR4 gene (rs4986790 and rs4986791) and susceptibility to CAD.

Material and methods. A systematic search of Web of Science, Embase, Scopus, PubMed, and Wanfang Med Online was undertaken. Case-control studies assessing the association of rs4986790 and rs4986791 with CAD risk were included. The odds ratio (OR) and 95\% confidence interval (CI) were used as the metric of choice for the evaluation of risk.

Results. The literature search generated 427 studies, of which 14 met the inclusion criteria, for a total of 13,927 participants. Our meta-analysis revealed a significant association between rs 4986791 and CAD risk in Asians using the dominant model ( $C T+\mathrm{TT}$ vs $C \mathrm{C}: \mathrm{OR}=0.35,95 \% \mathrm{Cl}=0.21-0.56, \mathrm{p}<0.001)$, heterozygote contrast (CT vs CC: $O R=0.32,95 \% \mathrm{Cl}=0.19-0.57, \mathrm{p}<0.001)$ and allele contrast ( T vs $\mathrm{C}: 0 \mathrm{R}=0.38,95 \% \mathrm{Cl}=0.25-$ $0.58, p<0.001)$. No significant association between rs 4986791 and CAD was observed among Caucasians. For rs 4986790, the results provided no evidence of an association with CAD risk.
\end{abstract}

Conclusions. Our analysis suggests that rs 4986791 is negatively associated with CAD risk in Asians but not in Caucasians. No association between rs4986790 and CAD risk was found.

Key words: polymorphism, coronary artery disease, meta-analysis, toll-like receptor 4
Cite as

Sheng J, Xu J. Association of coronary artery disease with tolllike receptor 4 genetic variants: A meta-analysis. Adv Clin Exp Med. 2019;28(5):651-658. doi:10.17219/acem/91791

DOI

10.17219/acem/91791

\section{Copyright}

Copyright by Author(s)

This is an article distributed under the terms of the

Creative Commons Attribution Non-Commercial License

(http://creativecommons.org/licenses/by-nc-nd/4.0/) 
Coronary artery disease (CAD) is the leading cause of death and disability worldwide. ${ }^{1}$ It presents in 2 main forms: myocardial infarction (heart attack) and angina. The 2013 Global Burden of Disease Study estimated that almost $30 \%$ of all deaths worldwide were caused by CAD. ${ }^{2}$ Although much of the risk of CAD is explained by conventional risk factors, a great deal remains unexplained. Epidemiological studies have suggested that genetic factors are involved in the pathogenesis of CAD. ${ }^{3}$ A number of studies have looked at associations between polymorphic variants in candidate genes and CAD. ${ }^{3}$ One potential candidate gene system is the toll-like receptor (TLR) family.

Toll-like receptors are transmembrane proteins expressed on immune cells. Toll-like receptor 4 is a well-characterized TLR family member with a leucine-rich extracellular domain and an intra-cellular domain with strong similarity to the interleukin 1 (IL-1) receptor. ${ }^{4}$ Toll-like receptor 4 is involved in the adaptive and innate immune responses by binding to microbial or endogenous molecules such as lipopolysaccharide (LPS), heat shock proteins and fibronectin. ${ }^{4}$ Toll-like receptor 4-ligand complexes activate signal transduction pathways via an enzymatic cascade, leading to increased pro-inflammatory cytokine expression..$^{5}$ The TLR4 gene is located on chromosome 9q32-q33. ${ }^{6}$ Genetic variants within TLR4 would alter TLR4 expression and thus increase or decrease the risk of CAD. Many epidemiological studies have assessed the association of 2 common single-nucleotide polymorphisms (SNPs) in the TLR4 gene - rs4986790 and rs4986791 - with CAD risk. However, owing to insufficient statistical power and various clinical and methodological factors, the findings remain inconsistent. We aimed to summarize the current evidence by systematically reviewing the literature and performing a meta-analysis.

\section{Material and methods}

\section{Search strategy}

This meta-analysis adhered to the guidelines for systematic reviews of genetic association studies. ${ }^{7}$ A literature search was implemented in the online databases Web of Science, Embase, Scopus, PubMed, and Wanfang Med Online to search for case-control studies evaluating the relationship of the TLR4 polymorphisms rs4986790 and rs4986791 with susceptibility to CAD. The search was limited to studies published between 1990 and 2017. Search terms included "genetic variant", "polymorphism", "coronary heart disease", "coronary artery disease", "toll-like receptor 4", and "susceptibility". Electronic database searches were supplemented with manual searches of the references of all relevant publications and review articles. The search and selection of studies were conducted by 2 researchers; disagreements were resolved by discussion until a consensus was reached.

\section{Eligibility criteria}

The studies included were required to meet all of the following conditions: 1 . involving human subjects; 2 . published in peer-reviewed journals in Chinese or English; 3. employing a case-control design; 4 . no overlap with other studies (if there was an overlap with another study, we included the study with the largest sample size); and 5. investigating the relationship between TLR4 polymorphisms rs4986790 and/or rs4986791 and the risk of CAD. Case status was defined as having a diagnosis of CAD confirmed with coronary angiography. We did not specify the HardyWeinberg equilibrium (HWE) as an inclusion criterion. Specific exclusion criteria included animal studies, familial studies and studies including only cases. The reason for excluding a study during the full-text screening was recorded.

\section{Data extraction and quality assessment}

The following data was extracted from each eligible study using a pre-made extraction form: the last name of the first author, country of origin, ethnicity, year of publication, diagnostic criteria, disease type, case and control sample size, and genotype counts for the cases and controls. Two researchers independently extracted data and reached consensus on all the items. The quality assessment of the studies was conducted according to the NewcastleOttawa Scale (NOS). ${ }^{8}$

\section{Statistical analysis}

We calculated unadjusted odds ratios (ORs) with corresponding confidence intervals (CIs) from the raw genotype frequency data. For groups with 0 events, we added 0.5 to each cell. Meta-analyses were carried out to investigate the association between CAD risk and the TLR4 polymorphisms in terms of allele contrast, heterozygote contrast, homozygote contrast, recessive model, and dominant model. The allele contrast compared the number of rare alleles with the number of common alleles in the cases and controls. The heterozygote contrast compared the number of heterozygotes with that of common homozygotes. The homozygote contrast compared the number of rare homozygotes with the number of common homozygotes. In the recessive model, we compared rare homozygotes with individuals carrying common alleles. In the dominant model, we compared individuals carrying rare alleles with individuals who were homozygous for common alleles. The degree of betweenstudy heterogeneity was assessed using the $\mathrm{I}^{2}$ statistic, and the significance of this statistic was assessed using Cochran's Q test. A p-value $<0.10$ or $\mathrm{I}^{2}>50 \%$ indicated a significant statistical heterogeneity across studies, ${ }^{9}$ allowing for the use of a random-effects model to estimate the combined effect. ${ }^{10}$ In addition to the overall analysis, 
which included all the available data, a subgroup analysis for each ethnic group was also performed. Sensitivity analyses were performed to investigate the impact of each study on the pooled OR. Publication bias was appraised with visual inspection of funnel plots, with asymmetry assessed formally using Egger's and Begg's tests. Stata software v. 12.0 (StataCorp LLC, College Station, USA) was used for all the statistical analyses.

\section{Results}

\section{Characteristics of the eligible studies}

The literature search resulted in a total of 427 potentially relevant citations that were screened at the first review stage. Of these, 198 were duplicates and were removed, leaving 229 studies for the screening of abstracts. Thirty-one studies were read in full and 17 studies were excluded. Ultimately, 14 case-control studies were included in the metaanalysis. ${ }^{11-24}$ Figure 1 presents a flow chart of the retrieved and excluded studies with the reasons specified. The eligible studies included populations from China, Croatia, France, Germany, Ireland, Italy, Mexico, Norway, Russia, Turkey, the USA, and the UK. The sample sizes in the 14 studies ranged from 240 to 4,868 . The characteristics of the studies included are summarized in Table 1.

\section{Data synthesis}

Tables 2 and 3 present the pooled ORs in detail. Seven studies including 6,886 cases and 2,682 controls dealt with the rs4986791 variant. ${ }^{16,17,19,21-24}$ The combined analyses of all the eligible studies produced no evidence of an association between rs4986791 and CAD risk using the dominant model $(\mathrm{OR}=0.85,95 \% \mathrm{CI}=0.59-1.23$; $\mathrm{p}=0.391)$, the recessive model $(\mathrm{OR}=0.80,95 \% \mathrm{CI}=0.46-$ 1.39; $\mathrm{p}=0.424)$, heterozygote contrast $(\mathrm{OR}=0.85,95 \%$ $\mathrm{CI}=0.59-1.23 ; \mathrm{p}=0.385)$, homozygote contrast $(\mathrm{OR}=0.76$, $95 \% \mathrm{CI}=0.44-1.32 ; \mathrm{p}=0.333)$, or allele contrast $(\mathrm{OR}=0.87$, 95\% CI = 0.61-1.23; p = 0.415) (Table 2, Fig. 2). However, the subgroup of Asian populations showed a strong association using the dominant model $(\mathrm{OR}=0.35,95 \% \mathrm{CI}=0.21-$ $0.56 ; \mathrm{p}<0.001)$, heterozygote contrast $(\mathrm{OR}=0.32,95 \%$ $\mathrm{CI}=0.19-0.57 ; \mathrm{p}<0.001)$ and allele contrast $(\mathrm{OR}=0.38$, 95\% CI = 0.25-0.58; $\mathrm{p}<0.001$ ) (Table 2, Fig. 2). We did not find a significant association between rs4986791 and CAD risk in Caucasians under any of the comparison models (Table 2, Fig. 2). There was evidence of heterogeneity among these studies $\left(\mathrm{I}^{2}=78.9 \%, \mathrm{p}<0.001\right)$ (Table 2 ). The sensitivity analyses showed that the results remained unchanged after removing each study in turn (Fig. 3).

Thirteen case-control studies with 8,762 cases and 4,712 controls provided results on associations between rs4986790 and CAD risk. ${ }^{11-18,20-24}$ We did not find evidence

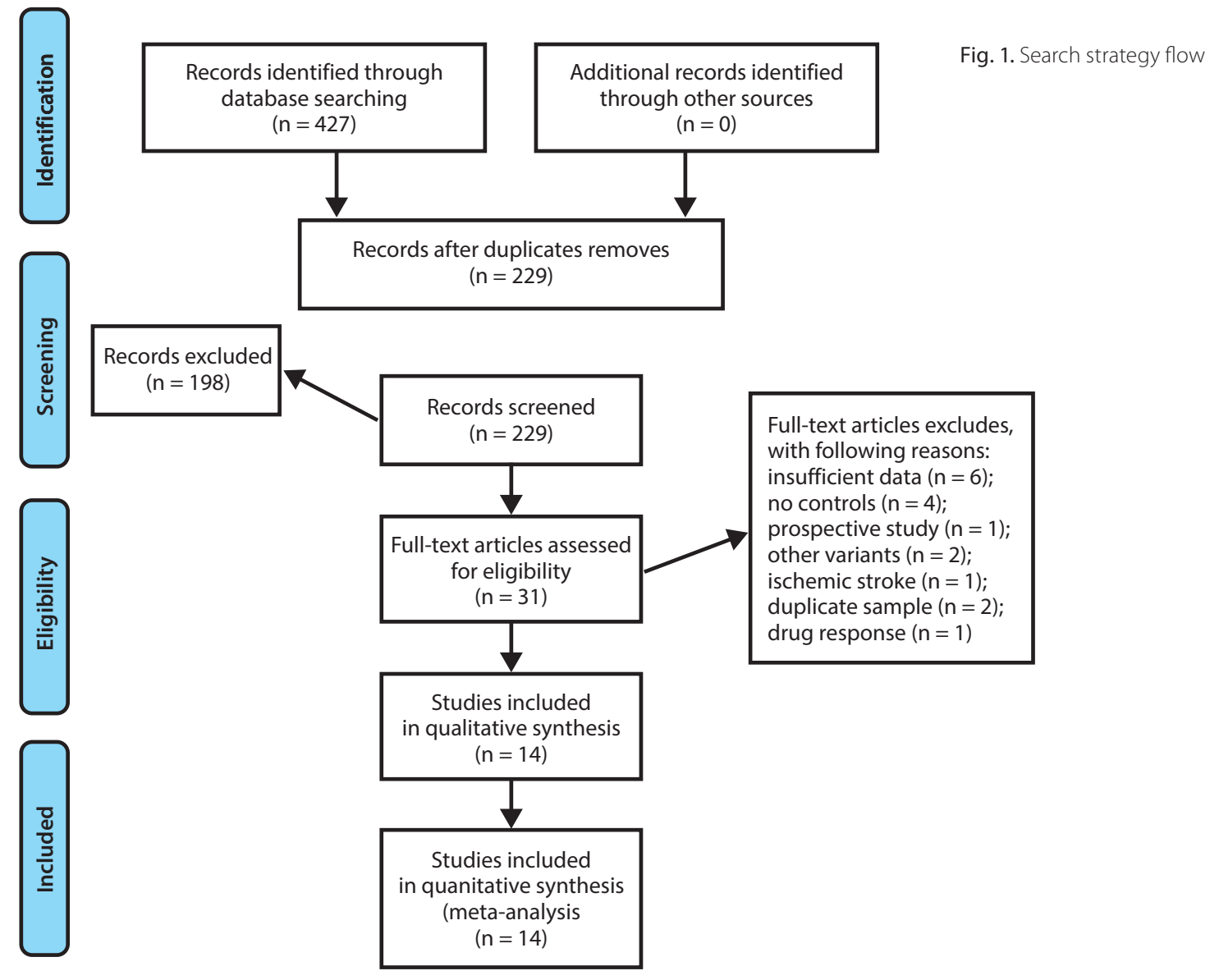


Table 1. Characteristics of individual studies included in the meta-analysis

\begin{tabular}{|c|c|c|c|c|c|c|c|c|c|}
\hline Author & Year & Ethnicity & Country & Cases & Controls & Control origin & $\begin{array}{l}\text { Data for } \\
\text { polymorphisms }\end{array}$ & Genotyping method & $\begin{array}{l}\text { NOS } \\
\text { score }\end{array}$ \\
\hline Ameziane & 2003 & Caucasian & France & 183 & 216 & hospital & rs4986790 & $\begin{array}{c}\text { TaqMan allelic discrimination } \\
\text { test }\end{array}$ & 7 \\
\hline Balistreri & 2004 & Caucasian & Italy & 105 & 182 & hospital & rs4986790 & Allele-specific PCR & 6 \\
\hline Morange & 2004 & Caucasian & France and UK & 247 & 490 & population & rs4986790 & Allele-specific PCR & 8 \\
\hline Zee & 2005 & Caucasian & USA & 370 & 695 & not specified & rs4986790 & $\begin{array}{l}\text { ABI Assay-by-Demand } \\
\text { allelic discrimination method }\end{array}$ & 7 \\
\hline Hamann & 2005 & Caucasian & $\begin{array}{l}\text { Germany and } \\
\text { UK }\end{array}$ & 388 & 163 & not specified & rs4986790 & $P C R$ & 7 \\
\hline O'Halloran & 2006 & Caucasian & Ireland & 1598 & 386 & population & $\begin{array}{l}\text { rs4986790 and } \\
\text { rs4986791 }\end{array}$ & Allele-specific PCR & 7 \\
\hline Koch & 2006 & Caucasian & Germany & 3657 & 1211 & hospital & $\begin{array}{l}\text { rs4986790 and } \\
\text { rs4986791 }\end{array}$ & Allele-specific PCR & 7 \\
\hline Nebel & 2007 & Caucasian & Germany & 606 & 323 & not specified & rs4986790 & TaqMan SNP Genotyping Assay & 7 \\
\hline Wang & 2009 & Asian & China & 156 & 172 & hospital & rs4986791 & PCR-RFLP & 8 \\
\hline Džumhur & 2012 & Caucasian & $\begin{array}{l}\text { Croatia and } \\
\text { Norway }\end{array}$ & 120 & 120 & hospital & rs4986790 & TaqMan SNP Genotyping Assay & 7 \\
\hline $\begin{array}{l}\text { Martínez- } \\
\text { Ríos }\end{array}$ & 2013 & $\begin{array}{l}\text { Latin } \\
\text { Americans }\end{array}$ & Mexico & 457 & 283 & hospital & $\begin{array}{l}\text { rs4986790 and } \\
\text { rs4986791 }\end{array}$ & TaqMan Genotyping Assay & 7 \\
\hline Golovkin & 2014 & Caucasian & Russia and UK & 702 & 300 & hospital & $\begin{array}{l}\text { rs4986790 and } \\
\text { rs4986791 }\end{array}$ & TaqMan SNP Genotyping Assay & 6 \\
\hline Guven & 2015 & Caucasian & Turkey & 300 & 150 & hospital & $\begin{array}{l}\text { rs4986790 and } \\
\text { rs4986791 }\end{array}$ & $\begin{array}{l}\text { Real-time PCR using } \\
\text { hybridization probes }\end{array}$ & 6 \\
\hline Li & 2017 & Asian & China & 167 & 180 & hospital & $\begin{array}{l}\text { rs4986790 and } \\
\text { rs4986791 }\end{array}$ & DNA sequencing & 7 \\
\hline
\end{tabular}

NOS - Newcastle-Ottawa scale; PCR - polymerase chain reaction; PCR-RFLP - PCR-restriction fragment length polymorphism; SNP - single nucleotide polymorphism.

Table 2. Meta-analysis of associations between rs4986791 and CAD risk

\begin{tabular}{|c|c|c|c|c|c|c|c|c|c|}
\hline \multirow{2}{*}{ Comparison } & \multirow{2}{*}{ Subgroup } & \multirow{2}{*}{$\begin{array}{l}\text { Number } \\
\text { of studies }\end{array}$} & \multicolumn{3}{|c|}{ Test of association } & \multicolumn{2}{|c|}{$\begin{array}{c}\text { Test } \\
\text { of heterogeneity } \\
\end{array}$} & \multicolumn{2}{|c|}{ Test of publication } \\
\hline & & & OR & $95 \% \mathrm{Cl}$ & $p$-value & $\mathrm{P}^{2}$ & p-value & $\begin{array}{l}\text { p-value for } \\
\text { Begg's test }\end{array}$ & $\begin{array}{l}\text { p-value for } \\
\text { Egger's test }\end{array}$ \\
\hline \multirow{3}{*}{$\begin{array}{l}\mathrm{CT}+\mathrm{TT} \text { vs CC } \\
\text { (dominant) }\end{array}$} & all & 7 & 0.85 & $0.59-1.23$ & 0.391 & 78.9 & $<0.001$ & 0.548 & 0.573 \\
\hline & Caucasians & 4 & 1.09 & $0.78-1.52$ & 0.622 & 69.9 & 0.019 & NA & NA \\
\hline & Asians & 2 & 0.35 & $0.21-0.56$ & $<0.001$ & 0.0 & 0.676 & NA & NA \\
\hline \multirow{3}{*}{$\begin{array}{l}\text { TT vs CT + CC } \\
\text { (recessive) }\end{array}$} & all & 7 & 0.80 & $0.46-1.39$ & 0.424 & 0.0 & 0.622 & 0.260 & 0.202 \\
\hline & Caucasians & 4 & 1.20 & $0.56-2.57$ & 0.648 & 0.0 & 0.733 & NA & NA \\
\hline & Asians & 2 & 0.47 & $0.19-1.15$ & 0.096 & 0.0 & 0.769 & NA & NA \\
\hline \multirow[b]{2}{*}{ CT vs CC } & all & 7 & 0.85 & $0.59-1.23$ & 0.385 & 77.2 & $<0.001$ & 0.368 & 0.513 \\
\hline & Caucasians & 4 & 1.07 & $0.75-1.52$ & 0.710 & 71.5 & 0.015 & NA & NA \\
\hline \multirow{3}{*}{ TT vs CC } & all & 7 & 0.76 & $0.44-1.32$ & 0.333 & 0.0 & 0.541 & 0.260 & 0.227 \\
\hline & Caucasians & 4 & 1.20 & $0.56-2.57$ & 0.642 & 0.0 & 0.747 & NA & NA \\
\hline & Asians & 2 & 0.42 & $0.17-1.03$ & 0.057 & 0.0 & 0.760 & NA & NA \\
\hline \multirow{3}{*}{ Tallele vs C allele } & all & 7 & 0.87 & $0.61-1.23$ & 0.415 & 79.3 & $<0.001$ & 0.764 & 0.643 \\
\hline & Caucasians & 4 & 1.10 & $0.81-1.48$ & 0.547 & 66.4 & 0.030 & NA & NA \\
\hline & Asians & 2 & 0.38 & $0.25-0.58$ & $<0.001$ & 0.0 & 0.615 & NA & NA \\
\hline
\end{tabular}

CAD - coronary artery disease; CI - confidence interval; NA - not applicable; OR - odds ratio. 


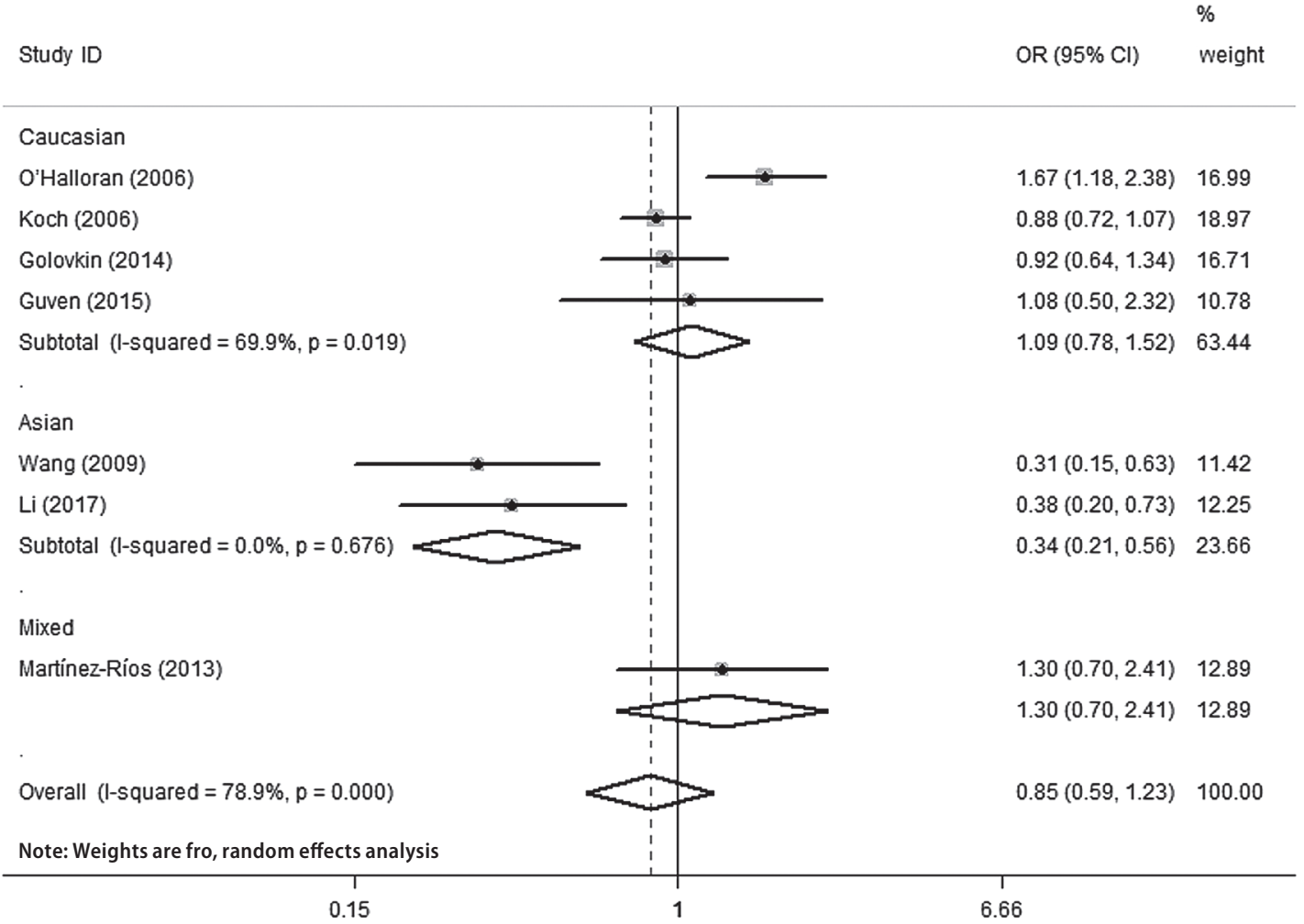

Fig. 2. Forest

plot for included

studies examining

the association

of rs4986791 with CAD

risk under the dominant model

Table 3. Meta-analysis of associations between rs4986790 and CAD risk

\begin{tabular}{|c|c|c|c|c|c|c|c|c|c|}
\hline \multirow[b]{2}{*}{ Comparison } & \multirow[b]{2}{*}{ Subgroup } & \multirow{2}{*}{$\begin{array}{l}\text { Number } \\
\text { of studies }\end{array}$} & \multicolumn{3}{|c|}{ Test of association } & \multicolumn{2}{|c|}{ Test of heterogeneity } & \multicolumn{2}{|c|}{ Test of publication } \\
\hline & & & OR & $95 \% \mathrm{Cl}$ & p-value & $\mathrm{I}^{2}(\%)$ & $p$-value & $\begin{array}{l}p \text {-value for } \\
\text { Begg's test }\end{array}$ & $\begin{array}{l}p \text {-value for } \\
\text { Egger's test }\end{array}$ \\
\hline \multirow{2}{*}{$\begin{array}{l}\mathrm{AG}+\mathrm{GG} \text { vs } \mathrm{AA} \\
\text { (dominant) }\end{array}$} & all studies & 13 & 0.94 & $0.76-1.17$ & 0.591 & 58.1 & 0.004 & 0.200 & 0.519 \\
\hline & Caucasians & 11 & 0.91 & $0.73-1.15$ & 0.445 & 64.0 & 0.002 & NA & NA \\
\hline \multirow{2}{*}{$\begin{array}{l}\text { GG vs } A G+A A \\
\text { (recessive) }\end{array}$} & all studies & 13 & 1.16 & $0.61-2.20$ & 0.656 & 0.0 & 0.947 & 1.000 & 0.726 \\
\hline & Caucasians & 11 & 1.12 & $0.54-2.12$ & 0.532 & 0.0 & 0.824 & NA & NA \\
\hline \multirow{2}{*}{$A G$ vs $A A$} & all studies & 13 & 0.94 & $0.76-1.16$ & 0.566 & 55.3 & 0.008 & 0.127 & 0.500 \\
\hline & Caucasians & 11 & 0.91 & $0.73-1.14$ & 0.420 & 61.4 & 0.004 & NA & NA \\
\hline \multirow{2}{*}{ GG vs $A A$} & all studies & 13 & 1.10 & $0.61-1.99$ & 0.693 & 0.0 & 0.934 & 1.000 & 0.727 \\
\hline & Caucasians & 11 & 1.09 & $0.60-1.97$ & 0.654 & 0.0 & 0.892 & NA & NA \\
\hline \multirow{2}{*}{ G allele vs A allele } & all studies & 13 & 0.95 & $0.78-1.17$ & 0.643 & 59.1 & 0.004 & 0.246 & 0.533 \\
\hline & Caucasians & 11 & 0.93 & $0.74-1.16$ & 0.494 & 64.9 & 0.001 & NA & NA \\
\hline
\end{tabular}

CAD - coronary artery disease; CI - confidence interval; NA - not applicable; OR - odds ratio.

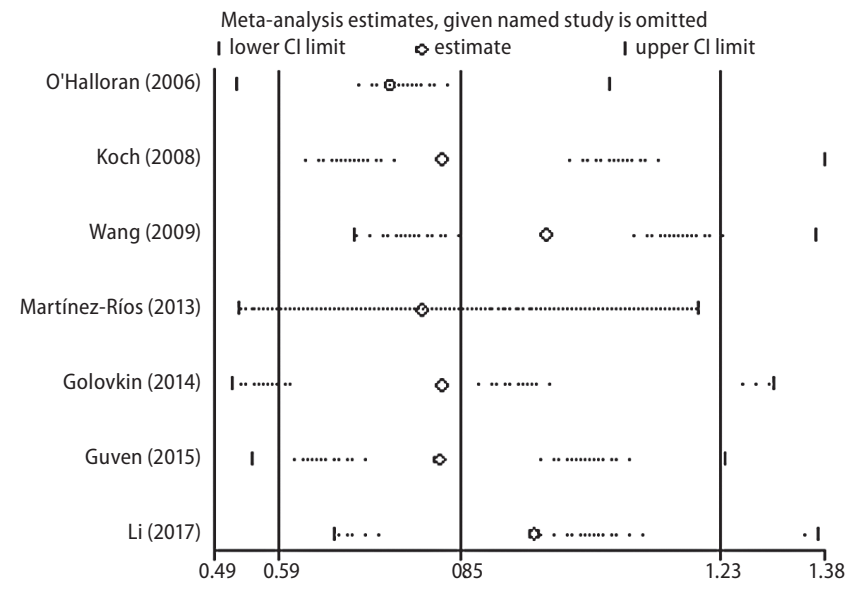

of an association between rs4986790 and CAD risk using the dominant model $(\mathrm{OR}=0.94,95 \% \mathrm{CI}=0.76-1.17$; $\mathrm{p}=0.591)$, the recessive model $(\mathrm{OR}=1.16,95 \% \mathrm{CI}=0.61-$ $2.20 ; \mathrm{p}=0.656)$, heterozygote contrast $(\mathrm{OR}=0.94,95 \%$ $\mathrm{CI}=0.76-1.16 ; \mathrm{p}=0.566)$, homozygote contrast $(\mathrm{OR}=1.10$, $95 \% \mathrm{CI}=0.61-1.99 ; \mathrm{p}=0.693)$, or allele contrast $(\mathrm{OR}=0.95$, 95\% CI = 0.78-1.17; p = 0.643) (Table 3, Fig. 4). Subgroup analyses by ethnicity did not identify any associations of this variant with CAD risk in Caucasians (Table 3,

Fig. 3. Sensitivity analysis for included studies assessing the association of rs4986791 with CAD risk under the dominant model 

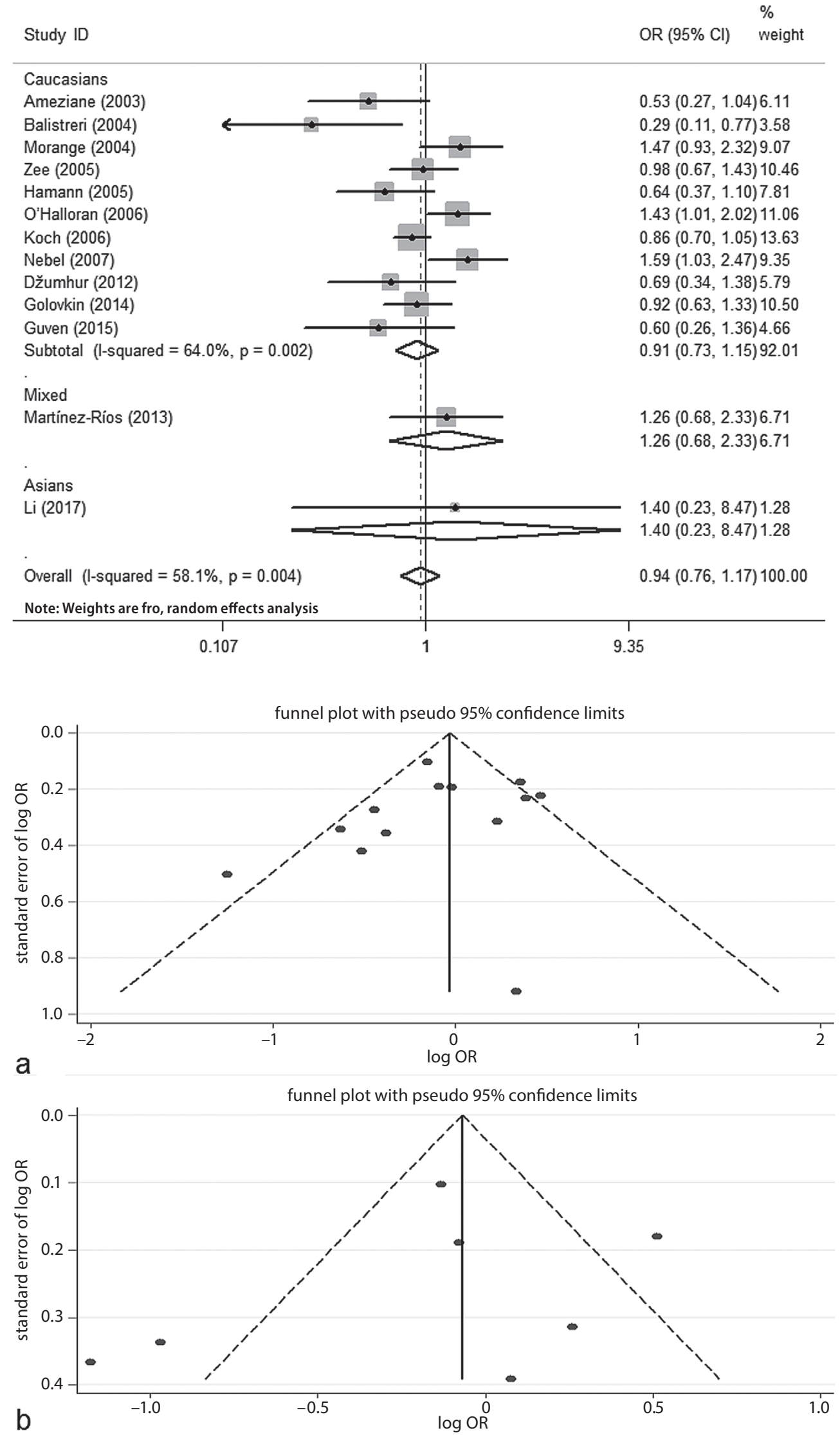

Fig. 4. Forest plot for included studies examining the association of rs4986790 with CAD risk under the dominant model
Fig. 5. (a) Funnel plot for included studies assessing the association of rs4986790 with CAD risk under the dominant model. (b) Funnel plot for included studies assessing the association of rs4986791 with CAD risk under the dominant model
Fig. 4). Since the number of studies performed in Asians and Latin Americans was limited, we did not conduct ethnicity-specific analyses in these ethnic groups. Moderate between-study heterogeneity was found among the studies (Table 3). The results of the sensitivity analysis for rs4986790 were virtually unchanged (not shown). 


\section{Publication bias}

Publication bias was evaluated by performing funnel plots and Egger's and Begg's tests under all models. For rs4986790 and rs4986791, the funnel plots were symmetrical (Fig. 5). Egger's and Begg's tests showed no evidence of publication bias (Table 2,3).

\section{Discussion}

Toll-like receptors constitute a major subgroup of pattern recognition receptors, responding to inter- and intracellular molecules typically associated with pathogens. To date, 10 functional human TLRs (TLR1-10) have been identified, among which TLR4 is a prominent member. ${ }^{4}$ Toll-like receptor 4 is expressed by a variety of immune and non-immune cells, including macrophages, neutrophils, endothelial cells, smooth muscle cells, and cardiac myocytes. ${ }^{5}$ It is activated by bacterial LPS or a number of endogenous ligands that are formed in pathological conditions. ${ }^{4}$ Activated TLR4 signals through the canonical nuclear factor- $\mathrm{kB}(\mathrm{NF}-\mathrm{k} \mathrm{B})$ pathway, resulting in the production of pro-inflammatory cytokines such as IL-1 $\beta$, IL-6 and tumor necrosis factor $\alpha$ (TNF- $\alpha) .{ }^{25}$ Toll-like receptor 4 has been shown to play an important role not only in the formation of atheromatous plaque, but also in the deterioration of the coronary arteries. ${ }^{25}$ Toll-like receptor 4 is necessary for oxidized low-density lipoprotein-induced macrophage differentiation into foam cells. ${ }^{26}$ Animal studies have demonstrated that apolipoprotein E-deficient mice additionally lacking TLR4 are resistant to atherosclerosis. ${ }^{27}$ In addition, mice lacking macrophage TLR4 expression have been found to have reduced atherosclerotic lesion size when fed low-fat diets. ${ }^{28}$ Human studies have demonstrated that expression levels of TLR4 in circulating monocytes and coronary plaques were significantly elevated in acute coronary syndrome (ACS) patients. ${ }^{29-31}$ Increased expression of TLR4, but not TLR2, has been observed in ruptured human coronary atherosclerotic plaque, suggesting that TLR4 plays a critical role in plaque instability. ${ }^{30}$ All of the above findings imply that the TLR4 gene may be a candidate marker for susceptibility to CAD.

In this meta-analysis, we combined data from published case-control studies to assess the relationship between 2 variants in the TLR4 gene - rs4986791 and rs4986790 - and CAD risk. The results suggest that the rs4986791 variant is protective against CAD in Asian populations but not in Caucasians. We did not find evidence of an association between the rs4986790 variant and susceptibility to CAD.

The rs4986791 variant, also known as Thr399Ile, is a functional polymorphism characterized by cytosine/ thymine transition at nucleotide 1196 , leading to a threonine (Thr) for isoleucine (Ile) substitution at amino acid 399 in the protein chain. ${ }^{6}$ In the vicinity of the mutation area, rs4986791 causes conformational changes, decreases the expression level of TLR4, reduces the binding efficiency of TLR4 with its ligands and affects the interactions of TLR4 with downstream signaling proteins. ${ }^{32-34}$ Since TLR4 is involved in the formation of atheromatous plaque and CAD pathogenesis, rs4986791 may reduce the risk of CAD by downregulating the expression level of TLR4 and modifying its functions. The results of our subgroup analyses for rs4986791 indicate that the association between rs4986791 and the risk of CAD may depend on the ethnicity of the study population. It is noteworthy that this is the first meta-analysis assessing the relationship between rs4986791 and CAD risk.

In addition to rs4986791, we investigated the association between rs4986790 and CAD risk, finding no evidence of association. The results for rs4986790 were in line with those of 2 prior meta-analyses. ${ }^{35,36}$ However, we could not exclude the possibility that rs4986790 along with other factors may have a synergistic effect on CAD risk. Boekholdt et al. found that among patients with coronary atherosclerosis, cardiovascular events, including myocardial infarction, were significantly decreased when statins were administered to carriers of the rs 4986790 G allele. ${ }^{37}$ Similar findings were obtained by Holloway et al. ${ }^{38}$ These results suggest that rs4986790 modified the efficacy of statins in preventing cardiovascular events. Interestingly, lifestyle-related risk factors like smoking may interact biologically with rs4986790 to alter the risk of CAD. A study by Edfeldt et al. found that a synergistic interaction between smoking and rs4986790 genotypes significantly affected the risk of CAD, implying that smoking was of special concern in the determination of rs4986790-mediated risk modification. ${ }^{39}$

Our meta-analysis has several limitations. First, only commonly investigated TLR4 variants assessed in $\geq 3$ studies could be included in the pooled analyses. Besides rs4986790 and rs4986791, the association between CAD and other TLR4 genetic variants, including rs11536889, rs10116253 and rs10983755, have also been evaluated by genetic studies. ${ }^{40}$ However, due to the limited published data, we were unable to include these variants in the present meta-analysis. Second, although Egger's and Beggs' tests and funnel plots did not reveal any evidence of publication bias, we could not exclude the possibility that some case-control studies obtaining negative results might not be published in peer-reviewed journals. Third, we could not exclude the possibility that several of the statistically significant associations from the eligible studies might be false-positive results. However, this is unlikely in our review, because we strictly selected the studies and evaluated their quality using the NOS scale.

\section{Conclusions}

In summary, this meta-analysis provides a comprehensive evaluation of the existing literature on the relation between 2 common genetic variants in TLR4 genes and 
the risk of CAD. The results suggest that the rs4986791 variant is negatively associated with CAD in Asians but not in Caucasians. There is no evidence of an association between the rs4986790 variant and CAD risk.

\section{References}

1. Sanchis-Gomar F, Perez-Quilis C, Leischik R, Lucia A. Epidemiology of coronary heart disease and acute coronary syndrome. Ann Transl Med. 2016;4(13):256.

2. Bhatnagar $P$, Wickramasinghe $K$, Williams J, Rayner M, Townsend N. The epidemiology of cardiovascular disease in the UK 2014. Heart. 2015;101(15):1182-1189.

3. Matyar S, Acartürk E, Attila G, Ünal I, Soyer L, Akpınar O. Gene-gene interaction of ACE I/D, endothelial nitric oxide synthase $4 \mathrm{a} / \mathrm{b}$ and ApoE does not affect coronary artery disease severity. Adv Clin Exp Med. 2014;23(2):215-223.

4. Ha T, Liu L, Kelley J, Kao R, Williams D, Li C. Toll-like receptors: New players in myocardial ischemia/reperfusion injury. Antioxid Redox Signal. 2011;15(7):1875-1893.

5. Roy A, Srivastava M, Saqib U, et al. Potential therapeutic targets for inflammation in Toll-like receptor 4 (TLR4)-mediated signaling pathways. Int Immunopharmacol. 2016;40:79-89.

6. Chrzeszczyk D, Konopka T, Ziętek M. Polymorphisms of Toll-like receptor 4 as a risk factor for periodontitis: Meta-analysis. Adv Clin Exp Med. 2015;24(6):1059-1070.

7. Sagoo GS, Little J, Higgins JP. Systematic reviews of genetic association studies. Human Genome Epidemiology Network. PLoS Med. 2009;6(3):e28.

8. Stang A. Critical evaluation of the Newcastle-Ottawa scale for the assessment of the quality of nonrandomized studies in meta-analyses. Eur J Epidemiol. 2010;25(9):603-605.

9. Higgins JP, Thompson SG, Deeks JJ, Altman DG. Measuring inconsistency in meta-analyses. BMJ. 2003;327(7414):557-560.

10. DerSimonian R, Laird N. Meta-analysis in clinical trials. Control Clin Trials. 1986;7(3):177-188.

11. Ameziane N, Beillat T, Verpillat $P$, et al. Association of the Toll-like receptor 4 gene Asp299Gly polymorphism with acute coronary events. Arterioscler Thromb Vasc Biol. 2003;23(12):e61-64.

12. Balistreri CR, Candore G, Colonna-Romano G, et al. Role of Toll-like receptor 4 in acute myocardial infarction and longevity. JAMA. 2004; 292(19):2339-2340.

13. Morange PE, Tiret L, Saut N, et al. TLR4/Asp299Gly, CD14/C-260T, plasma levels of the soluble receptor CD14 and the risk of coronary heart disease: The PRIME Study. Eur J Hum Genet. 2004;12(12):1041-1049.

14. Zee RY, Hegener HH, Gould J, Ridker PM. Toll-like receptor 4 Asp$299 \mathrm{Gly}$ gene polymorphism and risk of atherothrombosis. Stroke. 2005;36(1):154-157.

15. Hamann L, Gomma A, Schröder NW, et al. A frequent Toll-like receptor (TLR)-2 polymorphism is a risk factor for coronary restenosis. JMol Med (Berl). 2005;83(6):478-485.

16. O'Halloran AM, Stanton A, O'Brien E, Shields DC. The impact on coronary artery disease of common polymorphisms known to modulate response to pathogens. Ann Hum Genet. 2006;70(Pt 6):934-945.

17. Koch W, Hoppmann P, Pfeufer A, Schömig A, Kastrati A. Toll-like receptor 4 gene polymorphisms and myocardial infarction: No association in a Caucasian population. Eur Heart J. 2006;27(21):2524-2529.

18. Nebel A, Flachsbart F, Schäfer A, et al. Role of the Toll-like receptor 4 polymorphism Asp299Gly in longevity and myocardial infarction in German men. Mech Ageing Dev. 2007;128(5-6):409-411.

19. Wang JN, Liu B, Song CL. To study the TLRA gene polymorphism and its association with coronary heart disease. China Prac Med. 2009;4: 5-6.

20. Džumhur A, Zibar L, Wagner J, Simundić T, Dembić Z, Barbić J. Association studies of gene polymorphisms in Toll-like receptors 2 and 4 in Croatian patients with acute myocardial infarction. Scand J Immunol. 2012;75(5):517-523.
21. Martínez-Ríos MA, Vargas-Alarcón G, Vallejo M, et al. Toll-like receptor 4 gene polymorphisms and acute coronary syndrome: No association in a Mexican population. Arch Cardiol Mex. 2013;83(4):257-262.

22. Golovkin AS, Ponasenko AV, Khutornaya MV, et al. Association of TLR and TREM-1 gene polymorphisms with risk of coronary artery disease in a Russian population. Gene. 2014;550(1):101-109.

23. Guven M, Ismailoglu Z, Batar B, et al. The effect of genetic polymorphisms of TLR2 and TLR4 in Turkish patients with coronary artery disease. Gene. 2015;558(1):99-102.

24. Li SD, Nie Y, Sun YH, et al. Association of Toll-like receptor 2 and 4 gene polymorphisms with risk of coronary atherosclerotic artery disease in Hunan Han population [in Chinese]. J Cent South Univ (Med Sci). 2017;42(3):246-250.

25. Arslan F, de Kleijn DP, Pasterkamp G. Innate immune signaling in cardiac ischemia. Nat Rev Cardiol. 2011;8(5):292-300.

26. Howell KW, Meng X, Fullerton DA, Jin C, Reece TB, Cleveland JC Jr. Toll-like receptor 4 mediates oxidized LDL-induced macrophage differentiation to foam cells. J Surg Res. 2011;171(1):e27-31.

27. Michelsen KS, Wong MH, Shah PK, et al. Lack of Toll-like receptor 4 or myeloid differentiation factor 88 reduces atherosclerosis and alters plaque phenotype in mice deficient in apolipoprotein E. Proc Natl Acad Sci U S A. 2004;101(29):10679-10684.

28. Coenen KR, Gruen ML, Lee-Young RS, Puglisi MJ, Wasserman DH, Hasty $\mathrm{AH}$. Impact of macrophage Toll-like receptor 4 deficiency on macrophage infiltration into adipose tissue and the artery wall in mice. Diabetologia. 2009;52(2):318-328.

29. Methe H, Kim JO, Kofler S, Weis M, Nabauer M, Koglin J. Expansion of circulating Toll-like receptor 4-positive monocytes in patients with acute coronary syndrome. Circulation. 2005;111(20):2654-2661.

30. Fukushima R, Soejima H, Fukunaga T, et al. Expression levels of Tolllike receptor genes in coronary atherosclerotic lesions of patients with acute coronary syndrome or stable angina pectoris. Circ J. 2009; 73:(8)1479-1484.

31. Satoh S, Yada R, Inoue $H$, et al. Toll-like receptor-4 is upregulated in plaque debris of patients with acute coronary syndrome more than Toll-like receptor-2. Heart Vessels. 2016;31:1-5.

32. Apetoh L, Ghiringhelli F, Tesniere A, et al. Toll-like receptor 4-dependent contribution of the immune system to anticancer chemotherapy and radiotherapy. Nat Med. 2007;13(9):1050-1059.

33. Prohinar P, Rallabhandi P, Weiss JP, Gioannini TL. Expression of functional D299G.T399I polymorphic variant of TLR4 depends more on coexpression of MD-2 than does wild-type TLR4. J Immunol. 2010; 184(8):4362-4367.

34. Ohto U, Yamakawa N, Akashi-Takamura S, Miyake K, Shimizu T. Structural analyses of human Toll-like receptor 4 polymorphisms D299G and T3991. J Biol Chem. 2012;287(48):40611-40617.

35. Chen R, Gu N, Gao Y, Cen W. TLR4 Asp299Gly (rs4986790) polymorphism and coronary artery disease: A meta-analysis. PeerJ. 2015;3: e1412.

36. Wu BW, Zhu J, Shi HM, Jin B, Wen ZC. Association between Toll-like receptor 4 Asp299Glypolymorphism and coronary heart disease susceptibility. Braz J Med Biol Res. 2017;50(9):e6306.

37. Boekholdt SM, Agema WR, Peters RJ, et al. Variants of Toll-like receptor 4 modify the efficacy of statin therapy and the risk of cardiovascular events. Circulation. 2003;107(19):2416-2421.

38. Holloway JW, Yang IA, Ye S. Variation in the Toll-like receptor 4 gene and susceptibility to myocardial infarction. Pharmacogenet Genomics. 2005;15(1):15-21.

39. Edfeldt K, Bennet AM, Eriksson P, et al. Association of hypo-responsive Toll-like receptor 4 variants with risk of myocardial infarction. Eur Heart J. 2004;25(16):1447-1453.

40. Zhou L, Zheng D, Wang S, et al. Genetic association of Toll-like receptor 4 gene and coronary artery disease in a Chinese Han population. Springerplus. 2016;5(1):1533. 